\title{
Detection and characterization of Tomato spotted wilt virus infecting field and greenhouse-grown crops in Zimbabwe
}

\author{
Charles Karavina • Augustine Gubba
}

Accepted: 3 May 2017 / Published online: 9 May 2017

C) The Author(s) 2017. This article is an open access publication

\begin{abstract}
Tomato spotted wilt virus (TSWV), the type species of the genus Tospovirus in the family Bunyaviridae, is one of the most economically important emerging plant viruses worldwide. It causes over US $\$ 1$ billion losses annually in open field and greenhouse-grown crops. A study was carried out to determine the geographical distribution, host range and phylogeny of TSWV in Zimbabwe. Disease surveys were conducted in 18 districts over a three-year period using tospovirus immunostrips. Virus-infected leaf samples were collected on FTA cards and in RNAlater solution. TSWV was characterized by double antibody sandwich-enzyme linked immunosorbent assay (DASELISA) and reverse transcription polymerase chain reaction (RT-PCR) followed by sequencing and phylogenetic analysis. The virus was detected in $50 \%$ of the districts surveyed, mostly in the country's prime agricultural region. It was confirmed to be present by DASELISA and RT-PCR. In addition to some previously reported hosts, TSWV was detected for the first time in Cucurbita moschata, Cucurbita pepo, Cucumis
\end{abstract}

Electronic supplementary material The online version of this article (doi:10.1007/s10658-017-1243-4) contains supplementary material, which is available to authorized users.

C. Karavina · A. Gubba

Department of Plant Pathology, University of KwaZulu-Natal, Private Bag X01, Pietermaritzburg, South Africa

C. Karavina $(\bowtie)$

Department of Crop Science, Bindura University of Science

Education, Private Bag 1020, Bindura, Zimbabwe

e-mail: ckaravina@gmail.com sativus and Gyposphila elegans. Molecular analysis of the TSWV nucleocapsid gene showed that Zimbabwean TSWV isolates were highly similar $(\geq 93.99 \%)$ and identical $(99.02 \%)$ to each other at nucleotide and amino acid sequence levels. When compared to isolates from the rest of the world, Zimbabwean TSWV isolates were most closely related to isolates from Italy, Montenegro, New Zealand and Serbia. The study lays the foundation for future TSWV studies by providing protocols and procedures that could be used. Information generated in this study will be useful in formulating effective TSWV control measures.

Keywords Immunostrip · Host · Phylogenetic analysis · RT-PCR · Tospovirus

\section{Introduction}

Tomato spotted wilt virus (TSWV), the type species of the genus Tospovirus in the family Bunyaviridae, is one of the most economically important emerging plantinfecting viruses worldwide (Tsompana et al. 2005; Pappu et al. 2009; Scholthof et al. 2011). It causes losses estimated at US $\$ 1$ billion annually for several important ornamental, food and cash crops worldwide (Goldbach and Peters 1994; Parrella et al. 2003). It infects over 1300 species in more than 92 plant families (Parrella et al. 2003; EFSA 2012). Since its first report in Australia in 1915 (Brittlebank 1919), TSWV has been reported in over 60 countries worldwide. 
TSWV has a tripartite single-stranded RNA genome consisting of the large (L), medium (M) and small (S) RNA segments. The L RNA encodes the RNAdependent RNA polymerase in the negative sense. The M RNA encodes two proteins: the non-structural movement protein $(\mathrm{NSm})$ in the viral sense and the $\mathrm{Gn}-\mathrm{Gc}$ glycoprotein in the nonviral sense. The S RNA encodes the non-structural protein (NSs) in the viral sense and the nucleocapsid $(\mathrm{N})$ protein in the nonviral sense (Whitfield et al. 2005; Pappu et al. 2009). The TSWV virion is quasi-spherical, $80-120 \mathrm{~nm}$ diameter, and enveloped by a double membrane (German et al. 1992). Currently, at least nine thrips (Thysanoptera: Thripidae) species are known to transmit TSWV in a persistent-propagative manner, with Frankliniella occidentalis Pergande being the primary vector (Riley et al. 2011; Rotenberg et al. 2015).

The virus induces a wide range of symptoms in its hosts depending on environmental factors, host cultivar, pathogen strain and stage of host development (Sevik and Arli-Sokmen 2012). Common symptoms include ringspots, line patterns, mottling and chlorotic blotches on leaves, severe stunting, wilting, and even plant death. TSWV-infected young tomato (Solanum lycopersicum L.) plants are characterized by inward cupping of leaves, bronzing and deformed fruits which show uneven ripening and raised bumps on the surface (Sether and DeAngelis 1992). In pepper (Capsicum annuum L.), severe stunting and chlorotic or mosaic yellow flecking of leaves are observed in infected plants. Necrotic spots are also present on pepper fruits, which often display ring patterns (Turina et al. 2012).

In Zimbabwe, TSWV was first reported infecting tobacco (Nicotiana tabacum L.) in 1940 (Hopkins 1940). It was subsequently reported infecting at least 26 other vegetable, ornamental and weed species (Masuka et al. 1998; Nyamupingidza and Machakaire 2003). Recent studies have pointed out that the worldwide TSWV host range is expanding (Pappu et al. 2009), in part due to agricultural diversification and intensification, climate change, mutations and virus introductions into new habitats due to global trade in agricultural commodities (Hoffmann et al. 2001; Sharman and Persley 2006). New hosts are being reported mainly in tropical and sub-tropical environments where the disease is now prevalent (Robbins et al. 2010; Macharia et al. 2016). This necessitates the study of TSWV host range in a sub-tropical country like Zimbabwe.
Moreover, Zimbabwean TSWV records are outdated, with no new records since 1998 (Masuka et al. 1998). The available records do not indicate how TSWV detection and characterization were done. In the last three decades, advances in the discipline of virology have revolutionized plant virus diagnostics. For example, modern virological studies incorporating molecular assays followed by phylogenetic analyses have been employed to help avoid ambiguity in tospoviral identification (Okuda and Hanada 2001; Sivparsad and Gubba 2008). Correct TSWV identification is crucial for effective disease management.

In this study, we investigated the occurrence of TSWV in Zimbabwe. Specifically, we assessed the geographical distribution and host range, outlined protocols for the detection and characterization of Zimbabwean TSWV isolates, and assessed the phylogenetic relationship of Zimbabwean TSWV isolates to those isolates that occur worldwide.

\section{Materials and methods}

Sampling and field detection of tospoviruses

TSWV disease surveys were conducted from December 2013 to October 2015 in 18 districts across six provinces of Zimbabwe (Fig. 1). For Harare Province, the three surveyed districts were Harare East, Harare West and Harare North. The surveys targeted agricultural research institutions, irrigation schemes, plots, nutrition gardens, and commercial and communal farms where allyear-round cropping is practiced. Sampling was done in both open fields and greenhouses/ protected environments. Leaves exhibiting viruslike symptoms were tested on-site for tospoviruses before sample collection either onto FTA ${ }^{\mathrm{TM}}$ cards (Whatman International, USA) or in $2 \mathrm{~mL}$ microcentrifuge tubes in RNAlater ${ }^{\circledR}$ solution (Life Technologies, USA). Plant sap expressed onto FTA cards was air-dried for $30 \mathrm{~min}$ and stored at room temperature until processing. RNAlater Solutionpreserved samples were initially stored at $2-8{ }^{\circ} \mathrm{C}$ and later at $-80{ }^{\circ} \mathrm{C}$. In total, 1075 samples representing 13 different plant families were collected as follows: 429 samples in 2013, 381 samples in 2014, and 265 samples in 2015. Of these, 612 samples were collected on FTA cards while 


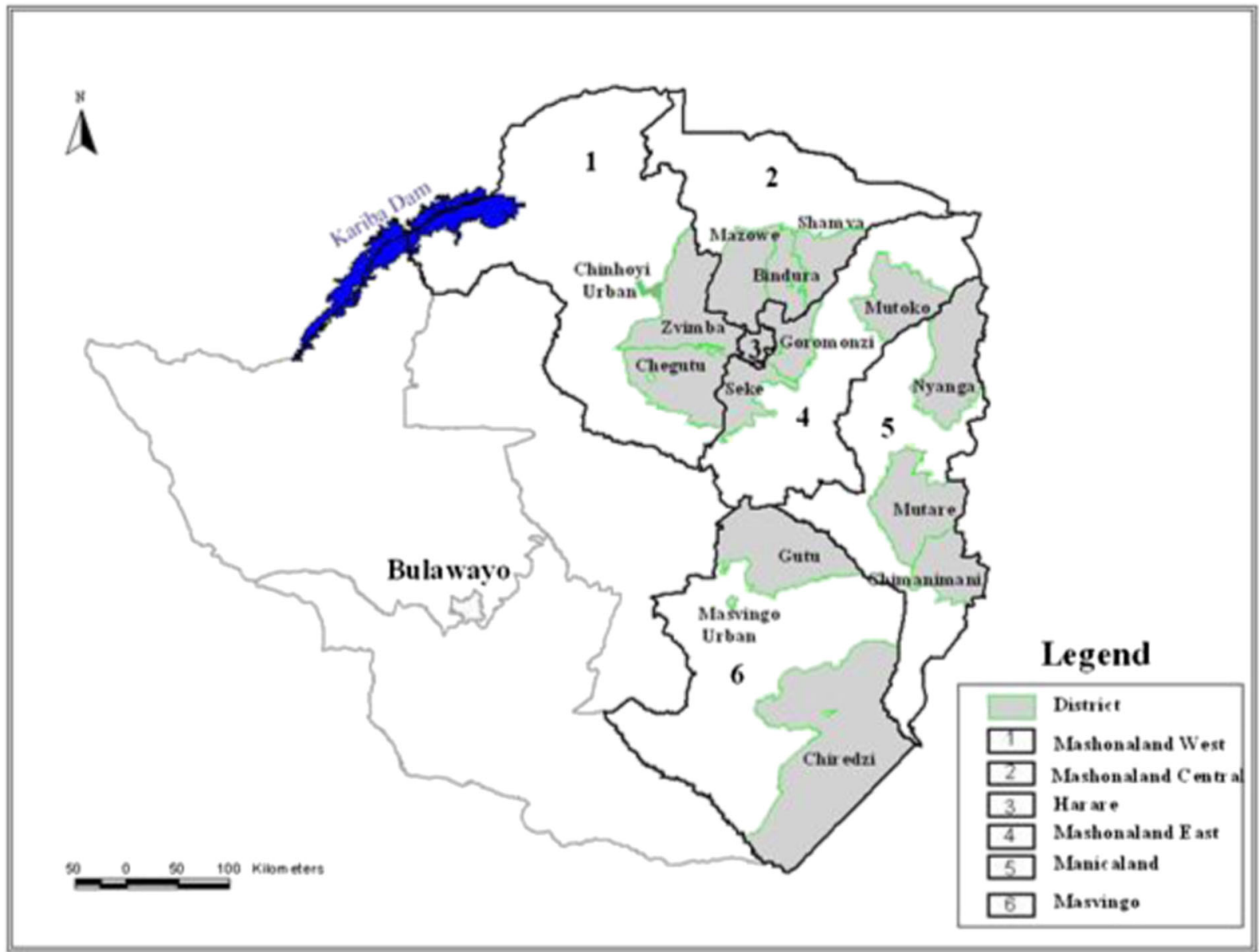

Fig. 1 Zimbabwean provinces (1-6) and districts surveyed for TSWV

463 samples were collected in RNAlater solution. All samples were transported to the University of KwaZulu-Natal, Plant Virology Laboratory (Pietermaritzburg, South Africa) for processing.

On-site Tospovirus detection was done using immunostrips (Loewe ${ }^{\circledR}$ Biochemica GmbH, Germany) that could simultaneously detect Tomato spotted wilt virus (TSWV), Tomato chlorotic spot virus (TCSV) and Groundnut ringspot virus (GRSV), according to manufacturer's instructions. Briefly, $5 \mathrm{~mm}$ diameter leaf discs of plants displaying tospovirus-like symptoms were collected into a small plastic bottle containing a buffer solution. The discs were ground using a plastic pestle. Two drops of the resultant sap were added to the test device window and observed for a color reaction in a viewing window. A control line appeared in the viewing window within a minute of sap application, while the test line appeared within 5-10 min in positive samples.
Double antibody sandwich enzyme-linked immunosorbent assay (DAS-ELISA)

All samples collected in RNAlater solution were analyzed with a commercial TSWV DAS-ELISA diagnostic kit (Loewe Biochemica GmbH, Germany) according to manufacturer's instructions. Briefly, $0.2 \mathrm{~g}$ of leaf samples were retrieved from the RNAlater solution using a sterile forcep. The RNAlater solution was removed from leaf samples by wiping the samples on paper towel. The samples were then submerged in $800 \mu \mathrm{L}$ extraction buffer solution (50 $\mathrm{mM}$ sodium phosphate containing $20 \mathrm{mM}$ sodium sylphite) in a $2 \mathrm{~mL}$ sterile microcentrifuge and then homogenized with a beads beater for $1 \mathrm{~min}$. The homogenate was centrifuged at $14,000 \mathrm{rpm}$ for $2 \mathrm{~min}$ and the lysate used for DASELISA. For every test, negative and positive controls were included. 
Molecular characterization of TSWV

\section{Nucleic acid extraction}

Total nucleic acid was extracted from FTA card samples as follows: a Harris ${ }^{\circledR}$ punch was used to cut out $4 \times 2 \mathrm{~mm}$ diameter discs from the card. The discs were place into a $2 \mathrm{~mL}$ microcentrifuge in $500 \mu \mathrm{L}$ nucleasefree water. The tube was pulse-vortexed for $30 \mathrm{~s}$. The discs were transferred to a new microcentrifuge tube to which $50 \mu \mathrm{L}$ water was added and pulse-vortexed for a further $15 \mathrm{~s}$. Thereafter, the discs were heated at $95{ }^{\circ} \mathrm{C}$ for $30 \mathrm{~min}$, pulse vortexed three times for $5 \mathrm{~s}$ and then centrifuged at $14800 \mathrm{rpm}$ for $5 \mathrm{~min}$. The discs were removed from the tube and the eluate was used to perform reverse transcription-polymerase chain reaction (RT-PCR).

Total RNA was extracted from leaf samples preserved in RNAlater solution using a Quick-RNATM MiniPrep Kit (Zymo Research, Irvine, USA) following the manufacturer's instructions. For each sample, about $0.5 \mathrm{~g}$ of leaf materials were ground in $2 \mathrm{~mL}$ microcentrifuge tubes using a bead beater. The RNA quality was assessed using a NanoDrop 1000 Spectrophotometer (Thermo Fisher Scientific, USA) and stored at $-80^{\circ} \mathrm{C}$.

Reverse transcription-polymerase chain reaction

First strand complementary DNA (cDNA) synthesis was performed using the RevertAid First Strand cDNA Synthesis Kit (Thermo Fisher Scientific, USA) using both degenerate and TSWV N gene primers (Table 1). Briefly, for each sample, $10 \mu \mathrm{L}$ RNA $(42 \mathrm{ng} / \mu \mathrm{L})$ was pre-heated at $65^{\circ} \mathrm{C}$ for $10 \mathrm{~min}$. Then, a $20 \mu \mathrm{L}$ reaction consisting of $4 \mu \mathrm{L}$ reaction buffer (250 mM Tris$\mathrm{HCl}, 250 \mathrm{mM} \mathrm{KCl}, 20 \mathrm{mM} \mathrm{MgCl} 2,50 \mathrm{mM} \mathrm{DTT}$ ), $1 \mu \mathrm{L}$ RevertAid M-MuLV Reverse Transcriptase enzyme (200 nmol of dTMP/ $\mu \mathrm{L}), 1 \mu \mathrm{L}$ RiboLock RNase Inhibitor $(20 \mathrm{u} / \mu \mathrm{L}), 2 \mu \mathrm{L}$ dNTPs $(10 \mathrm{mM}$ mix), $2 \mu \mathrm{L}$ reverse primer $(10 \mu \mathrm{M})$ and the preheated template RNA, was performed. The reaction mixture was incubated at $42{ }^{\circ} \mathrm{C}$ for $60 \mathrm{~min}$, followed by a $5 \mathrm{~min}$ termination step at $70{ }^{\circ} \mathrm{C}$. The resultant cDNA was used to perform polymerase chain reaction (PCR).

PCR was undertaken using the primer sets listed in Table 1. The primer pair gM410/gM870C amplifies the NSm protein, while all the other primers amplify the $\mathrm{N}$ gene. One-step $20 \mu \mathrm{L}$ PCR reactions consisting of $3 \mu \mathrm{L}$ cDNA, $2 \mu \mathrm{L}$ of each primer $(10 \mu \mathrm{M}), 10 \mu \mathrm{L}$ KAPA $2 \mathrm{G}$ HotStart Ready Mix $(0.5 \mathrm{U} / \mu \mathrm{L}$ DNA polymerase, $1.5 \mathrm{mM} \mathrm{MgCl} 2,0.2 \mathrm{mM}$ of each dNTP) and nucleasefree water were performed. Amplifications were carried out under the following cycling conditions: an initial denaturation at $95^{\circ} \mathrm{C}$ for $2 \mathrm{~min} ; 35$ cycles of denaturation at $95{ }^{\circ} \mathrm{C}$ for $15 \mathrm{~s}$, annealing at the appropriate temperature for each primer pair (Table 1) for $15 \mathrm{~s}$ and extension at $72{ }^{\circ} \mathrm{C}$ for $15 \mathrm{~s}$; followed by an incubation period at $72{ }^{\circ} \mathrm{C}$ for $5 \mathrm{~min}$. The PCR products were visualized by electrophoresis on $1.5 \%$ agarose gel stained with SYBR Safe Gel stain (Life Technologies, USA).

Cloning, sequencing and phylogenetic analysis

PCR products corresponding to targeted genes were purified using a QIAQuick DNA Purification Kit (Qiagen, Hilden, Germany) following the manufacturer's

Table 1 Primers used for the successful detection of Tomato spotted wilt virus in Zimbabwe

\begin{tabular}{|c|c|c|c|c|c|}
\hline Primer name & Target gene & $\begin{array}{l}\text { Amplicon size } \\
\text { (bp) }\end{array}$ & Primer sequence & $\begin{array}{l}\text { Annealing } \\
\text { temperature } \\
\left({ }^{\circ} \mathrm{C}\right)\end{array}$ & Source \\
\hline gM410 & $\mathrm{NSm}$ & 500 & AACTGGAAAAATGATTYNYTTGTTGG & 53.3 & Chen et al. (2012). \\
\hline gM870c & & & ATTAGYTTGCAKGCTTCAATNAARGC & & \\
\hline TSW 1 & $\mathrm{~N}$ & 628 & TCTGGTAGCATTCAACTTCAA & 51.7 & Roberts et al. (2000). \\
\hline TSW 2 & & & GTTTCACTGTAATGTTCCATAG & & \\
\hline TSWV 722 & $\mathrm{~N}$ & 620 & GCTGGAGCTAAGTATAGCAGC & 55.4 & Adkins and Rosskopf (2002). \\
\hline TSWV 723 & & & CACAAGGCAAAGACCTTGAG & & \\
\hline TSWV-N-1F & $\mathrm{N}$ & 777 & ATGTCTAAGGTTAAGCTCACTA & 51.3 & Navarre et al. (2009). \\
\hline TSWV-N-777c & & & TTAAGCAAGTTCTGTGAGTTTT & & \\
\hline
\end{tabular}


instructions. Purified products were either directly sequenced or cloned to $\mathrm{pCR} \circledast_{2} .1$ vector before sequencing at Inqaba Biotechnical Industries (Pretoria, South Africa). Cloning was performed using the TOPO-TA Cloning Kit (Invitrogen, USA) according to the manufacturer's instructions. The cloning vector with the ligated insert was used to transform TOP10 Chemically Competent Escherichia coli cells, according to manufacturer's instructions (Invitrogen, USA). Plasmid DNA of independently transformed bacterial cells was purified using the Zyppy ${ }^{\mathrm{TM}}$ Plasmid Miniprep Kit (Zymo Research, USA). Recombinant clones were identified by EcoRl restriction endonuclease digestion. Three independent clones for each insert were selected and sequenced in both directions using M13 primers.

Raw sequence data were checked for quality, edited and consensus sequences were compiled using MEGA6 software. The Basic Local Alignment Search Tool (BLAST) embedded in MEGA6 program was used to search the National Centre for Biotechnology Information (NCBI) GenBank for related TSWV N gene sequences (Supplementary Table 1) used in phylogenetic analysis. All sequences were aligned using ClustalW imbedded in the MEGA6 software (Tamura et al. 2013). The evolutionary history was inferred by using the Maximum Likelihood method based on the Tamura 3-parameter model with a discrete Gamma distribution generated by MEGA 6.0 (Tamura 1992). The bootstrap consensus tree inferred from 1000 replicates is taken to represent the evolutionary history of the taxa analyzed. Branches corresponding to partitions reproduced in less than $75 \%$ bootstrap replicates were collapsed. Iris yellow spot virus (Accession code AF001387.1) was used as an outgroup. Nucleotide identity and similarity were determined using the SIAS software program (www. imed.ucm.es/Tools/sias.html).

\section{Results}

Geographical distribution of TSWV in Zimbabwe

Out of the 18 districts surveyed, tospoviruses were detected in Harare (West, East and North), Seke, Goromonzi, Mutoko, Shamva, Mazoe and Zvimba (see Fig. 1). The virus was not detected in Bindura, Chegutu, Chimanimani, Chinhoyi Urban, Chiredzi, Gutu, Mutare, Nyanga and Masvingo Urban. TSWV was mainly detected at farms where there is all-year round cropping. The majority $(63 \%)$ of the TSWVpositive sites were within a $30 \mathrm{~km}$ radius of Harare Central Business District.

Field detection of tospoviruses using immunostrips

Tospoviruses were successfully detected from plants displaying leaf chlorosis, necrosis, crinkling and reduced size using immunostrips. The time it took for the test line to appear in the test device window and the intensity of the line varied from sample to sample. Tospovirus incidence was highest in Solanaceae $(11.8 \%)$ and Cucurbitaceae $(6.3 \%)$ families. There were inconclusive test results from lettuce (Lactuca sativa L.), onion (Allium cepa L.), begonia (Begonia sp.), baby's breath (Gypsophila elegans) and asters (Aster chinensis). Inconclusive results appeared either as faint test lines or after the standard 10 min viewing period. Tospoviruses were not detected in Leguminosae and Brassicaceae crops (Table 2) even though they supported high thrips populations and had virus-like infection symptoms.

\section{Serological characterization of TSWV}

Of the 663 samples tested by DAS-ELISA, only 96 (14.47\%) were positive for TSWV. The majority $(55.2 \%)$ of the positive samples belonged to the Solanaceae family, while $20.8 \%$ belonged to the Cucurbitaceae family. The alliums, basil, begonia, lettuce and peas samples that were inconclusive with immunostrips were negative by DAS-ELISA, while Gypsophila elegans samples were positive by DASELISA. TSWV was not detected in Brassicaceae and Leguminosae samples by DAS-ELISA.

Molecular and phylogenetic analyses

Amplification products of the expected sizes were detected after agarose electrophoresis of the RT-PCR products of total RNA isolations from leaf material infected with TSWV. The negative controls showed no products. Because of high similarities amongst the TSWV sequences, only representative sequences were deposited into GenBank with the accession codes given in Table 3 . None of the samples that had been negative by DASELISA were positive by PCR even when different primers were used. 
Table 2 List of crops and ornamental plants tested for tospoviruses using immunostrips

\begin{tabular}{|c|c|c|c|c|}
\hline \multirow{2}{*}{$\begin{array}{l}\text { Table } 2 \text { List of crops and orna- } \\
\text { mental plants tested for } \\
\text { tospoviruses using immunostrips }\end{array}$} & Family & Common name & Botanical name & Test result \\
\hline & Alliaceae & Onion & Allium сера & $\mathrm{NC}$ \\
\hline & & Garlic & A. sativum & $\mathrm{NC}$ \\
\hline & & Leek & A. ampeloprasum & $\mathrm{NC}$ \\
\hline & & Shallot & A. aggregatum & $\mathrm{NC}$ \\
\hline & Amaranthaceae & Spinach & Spinacia oleraceae & - \\
\hline & Asteraceae & Chrysanthemum & Chrysanthemum morifolium & + \\
\hline & & Aster & Callistephus chinensis & - \\
\hline & Begoniaceae & Begonia & Begonia spp & $\mathrm{NC}$ \\
\hline & Brassicaceae & Cabbage & Brassica oleracea & - \\
\hline & & Rape & B. napus & - \\
\hline & & Broccoli & B. oleracea & - \\
\hline & & Cauliflower & B. oleracea capitate & - \\
\hline & Caryophyllaceae & Baby's breath & Gypsophyla elegans & $\mathrm{NC}$ \\
\hline & Cucurbitaceae & Cucumber & Cucumis sativa & + \\
\hline & & Butternut & Cucurbita moschata & + \\
\hline & & Baby marrow & Cucurbita pepo & - \\
\hline & & Pumpkin & Cucurbita pepo & + \\
\hline & & Watermelon & Citrulus lanatus & - \\
\hline & & Gourds & Lagenaria siceraria & - \\
\hline & Gesneriaceae & African violet & Saintpaulia spp & - \\
\hline & Lamiaceae & Basil & Ocimum basilicum & $\mathrm{NC}$ \\
\hline & Leguminosae & Peas & Pisum sativum & $\mathrm{NC}$ \\
\hline & & Beans & Phaseolus vulgaris & - \\
\hline & & Soyabean & Glycine $\max$ & - \\
\hline & & Groundnut & Arachis hypogeae & - \\
\hline & & Cowpea & Vigna unguiculata & - \\
\hline & Roseceae & Roses & Rosa spp & - \\
\hline & Rubiaceae & Pentas & Pentas spp & - \\
\hline & Solanaceae & Potato & Solanum tuberosum & + \\
\hline & & Tomato & Solanum lycopersicum & + \\
\hline & & Tobacco & Nicotiana tabacum & - \\
\hline & & Cherry pepper & Capsicum annuum & + \\
\hline & & Bell pepper & Capsicum annuum & + \\
\hline & & Eggplant & Capsicum melongena & + \\
\hline & & Chilli pepper & Capsicum frutescens & $\mathrm{NC}$ \\
\hline '+' - positive; '-' - negative; 'NC' & Violaceae & Viola & Viola spp. & - \\
\hline
\end{tabular}

'+' - positive; '-' - negative; 'NC' - inconclusive
The BLAST results confirmed that the identified isolates were TSWV, based on the high levels of sequence similarities with TSWV isolates from other countries. When compared, the partial $\mathrm{N}$ gene of the Zimbabwean isolates showed at least $99.02 \%$ and $93.99 \%$ nucleotide and amino acid sequence identities and similarities, respectively. Isolate 81-cherry-zim (Accession code KX192329) had the lowest similarity (93.99-99.51\%) to the other
Zimbabwean isolates (Tables 4 and 5). When compared to isolates from elsewhere in the world (Supplementary Table 1), Zimbabwean isolates were most closely related to isolates from Italy (Accession code KM096540), New Zealand (Accession code KC494501) and Montenegro (Accession code GU355939) at 98.64-99.15\% nucleotide sequence identity. The Zimbabwean isolates were most similar to the Montenegrin isolate (code GU355939) and 
Table 3 Accession codes of Tomato spotted wilt virus isolates detected in different hosts in this study

\begin{tabular}{|c|c|c|c|c|}
\hline Accession code & Isolate name & Host name & Family & Sequenced gene \\
\hline KT732271 & Butternut_Harare & Cucurbita moschata & Cucurbitaceae & Nucleocapsid \\
\hline KU892656 & 92-tom1-zim & Solanum lycopersicum & Solanaceae & Nucleocapsid \\
\hline KX192331 & 90-eggplant-zim & S. melongena & Solanaceae & Nucleocapsid \\
\hline KX192332 & 86-potato-zim & S. tuberosum & Solanaceae & Nucleocapsid \\
\hline KU884650 & mum-a5 & Chrysanthemum morifolium & Asteraceae & Non-structural movement \\
\hline KU884651 & tom 16 & S. lycopersicum & Solanaceae & Non-structural movement \\
\hline KU671049 & 174_TSWV & Capsicum annuиm & Solanaceae & Nucleocapsid \\
\hline KU884648 & 42-pep-zim & C. апnиит & Solanaceae & Nucleocapsid \\
\hline KX192330 & a5-mum & C. morifolium & Asteraceae & Nucleocapsid \\
\hline KX273062 & gyp-316-zim & Gypsophila elegans & Asteraceae & Nucleocapsid \\
\hline KX192329 & 81-cherry-zim & C. annuum & Solanaceae & Nucleocapsid \\
\hline KX273061 & cuc-48-zim & Cucumis sativus & Cucurbitaceae & Nucleocapsid \\
\hline
\end{tabular}

Serbian isolate (code GU339805) at 99.36\%. The partial NSm gene of the Zimbabwean isolates showed 97-99\% similarities to isolates from Australia (HM015516), Serbia (GQ373174.1), USA (AY744486), Italy (HQ830185.1) and Spain (HM015511.1).

Phylogenetic analysis with the Maximum Likelihood method separated all isolates into two clusters (Fig. 2). All Zimbabwean isolates were in Cluster A with isolates from Algeria, Egypt, Kenya, some European, Asian, and the American countries. Cluster B had isolates from South Africa, China, Syria, Bulgaria, Brazil, Turkey, South Korea and Texas (USA). The Zimbabwean isolates grouped into a distinct sub-cluster in Cluster A.

\section{Discussion}

The study confirmed the presence of TSWV in Zimbabwe, a pathogen first reported in 1940 (Hopkins 1940). It was detected in $50 \%$ of the surveyed districts. TSWV was not detected in some districts even though two of its vectors, Frankliniella occidentalis and Thrips tabaci, were detected (data not shown). This could be due to the fact that there has been limited movement of infected plant material and/ or vectors within the country. Eight of the nine districts where TSWV was detected are in agro-ecological region II, the country's bread basket region. Any serious future TSWV disease outbreaks could be disastrous given the economic damage the disease causes (Cho et al. 1996; Pappu et al. 2009).
In this study, immunostrips were used to detect TSWV for the first time in Zimbabwe. This is important as immunostrips provide an easier-to-use and quicker detection technique than DAS-ELISA, electron microscopy and molecular assays. Immunostrip-use during field sampling ensured that mostly virus-positive samples were collected for further processing in the laboratory. The time variation in the appearance of the test line in test device window was probably due to differences in virus titre within the samples. The test line quickly appears in those samples that have high virus titre and vice versa (Strange 2003). Similarly, inconclusive results could be due to low virus titre or cross-reaction of antibodies with plant sap (Naidu et al. 2003).

The use of RNAlater solution and FTA cards during sampling was important as it enabled virus-infected samples to be conveniently transported to the laboratory for further characterization. In this case, there was no need for dry ice and/or refrigeration facilities to preserve RNA integrity in the collected samples. Crucially, RNAlaterstored samples were successfully used in TSWV detection by DAS-ELISA. Stabilization buffers are said to contain enzyme inhibitors that potentially interfere with ELISA. We did not observe such interference either in this or the other studies where we screened samples for Iris yellow spot virus (Karavina and Gubba 2017a, 2017b) and other viruses (data not shown). RNAlater-stored samples had previously been used to perform ELISA by Blacksell et al. (2004) and Rader et al. (2008).

The identity of the virus detected by immunostrips and DAS-ELISA was confirmed by molecular assays. 


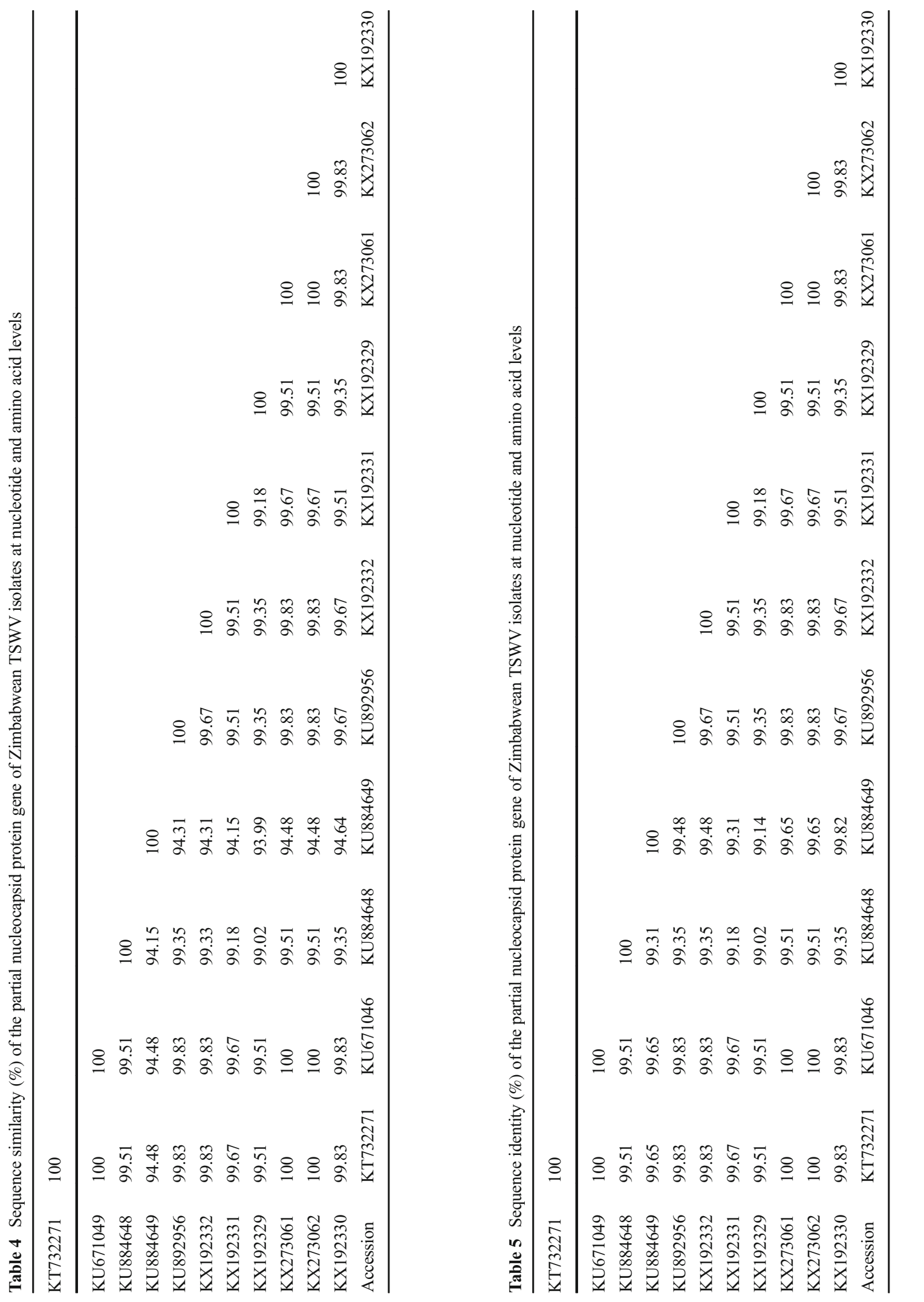




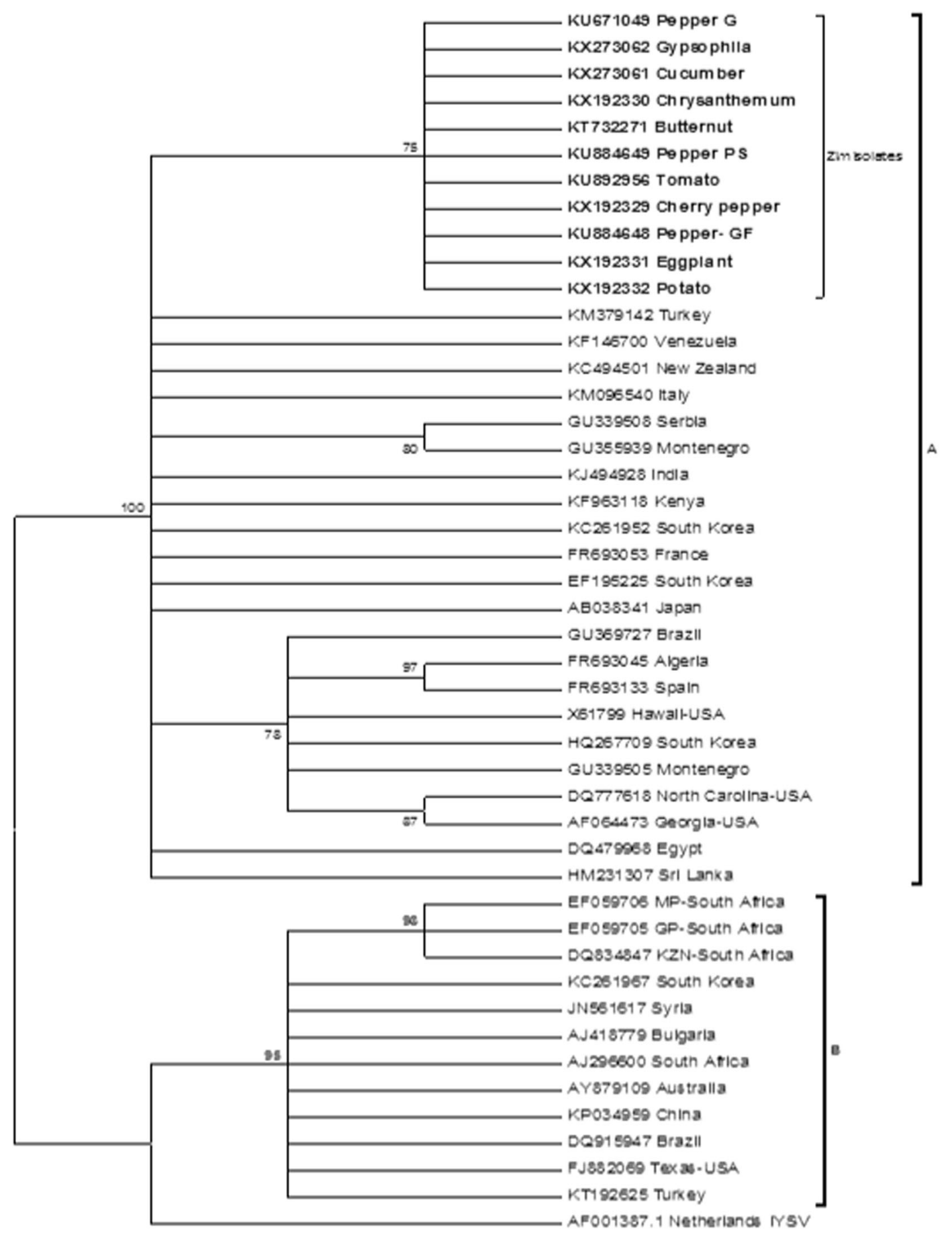

Fig. 2 Phylogenetic relationships of partial $\mathrm{N}$ gene sequences of TSWV isolates collected from Zimbabwe and database sequences from other geographical regions of the world. The evolutionary history was inferred using the Maximum Likelihood method based on the Tamura 3-parameter model. The bootstrap consensus tree

The molecular assays also helped to resolve the TSWV status of samples that had been inconclusive and/or inferred from 1000 replicates is taken to represent the evolutionary history of the taxa analyzed. Branches corresponding to partitions reproduced in less than $75 \%$ bootstrap replicates are collapsed. Zimbabwean isolates (Zim isolates) are printed in bold font

negative by serology. This is the first time molecular assays had been employed in characterizing TSWV in 
Zimbabwe. Given that there were no records of how TSWV was characterized in Zimbabwe, this study provides protocols that could either be adapted or adopted by other researchers studying the pathogen. Crucially, the protocols could enable early detection and correct characterization of TSWV for effective disease management (Awondo et al. 2012).

Host range records indicate that Zimbabwean TSWV was prevalent mainly in ornamentals and solanaceous crops (Rothwell 1982; Masuka et al. 1998). Amongst the ornamentals, this study detected the virus in Chrysanthemum morifolium and Gypsophila elegans only. The narrow ornamental host range observed could be attributed to the fact most of the flowers previously reported to be TSWV hosts are no longer being grown in the country. Zimbabwe's land reform program negatively impacted the floriculture sector as "new farmers" concentrated on maize, soybean and tobacco production at the expense of flowers which are highly capital-intensive. For the first time, TSWV was detected in the cucurbits Cucucrbita moschata, C. pepo and Cucumis sativus, an indication that the host range is expanding. Worldwide, TSWV infects over 1300 plant species (Parrella et al. 2003), and this host range is also expanding (Nischwitz et al. 2006; Pappu et al. 2009). Host range expansion is attributed to the generalist and opportunistic survival mode of TSWV (Pappu and Subramanian 2013). Though TSWV was not detected in all cucurbits grown in Zimbabwe, there is high likelihood of the virus infecting them in future, as has been reported elsewhere (Sether and DeAngelis 1992; Massumi et al. 2007). So, there is need for regular surveys to monitor the TSWV host range.

TSWV was mostly detected in solanaceous crops, indicating that they are highly susceptible to the virus. Of the solanaceous crops, infected tomatoes did not display severe disease symptoms. This could be attributed to the fact that most tomato varieties grown in Zimbabwe have the $S w-5 b$ resistance gene (data not shown). The virus was not detected in tobacco, a major cash crop in Zimbabwe. Local tobacco breeding programs incorporate TSWV resistance, and local TSWV isolates probably have not yet been able to break the resistance.

The fact that Zimbabwean TSWV isolates have high nucleotide and amino acid identity and similarities shows that minor evolutionary differences exist amongst the isolates. However, the minor isolate differences are evidence of some mutations taking place. There is need to carry out population genetics studies to investigate the systematic and random forces of evolution acting on the isolates.

Besides Zimbabwean isolates, the only other African TSWV isolate sequences that could be retrieved from sequence databases are from Kenya (Macharia et al. 2015), South Africa (Sivparsad and Gubba 2008), Egypt and Algeria. The Zimbabwean isolates clustered in the same group with Algerian, Egyptian and Kenyan isolates, but separately from South African isolates. This suggests that there may have been multiple introductions of TSWV into Africa (Sivparsad and Gubba 2008). The TSWV isolates in this study did not group according to geographical origin, as previously reported by Zindovic et al. (2014). This could be due to global trade in plant products which has resulted in TSWV strains spreading throughout the world.

In conclusion, the study revealed that TSWV in Zimbabwe is not as geographically widespread as its two worldwide vectors, F. occidentalis and T. tabaci. However, the virus host range is expanding. The virus detection techniques and characterization protocols employed to study TSWV could be employed to characterize other plant viruses in Zimbabwe.

\section{Compliance with ethical standards}

Ethical statement This research did not involve any animal and/ or human participants. The authors declare that they have no conflict of interests.

Open Access This article is distributed under the terms of the Creative Commons Attribution 4.0 International License (http:// creativecommons.org/licenses/by/4.0/), which permits unrestricted use, distribution, and reproduction in any medium, provided you give appropriate credit to the original author(s) and the source, provide a link to the Creative Commons license, and indicate if changes were made.

\section{References}

Adkins, S., \& Rosskopf, E. N. (2002). Key West nightshade, a new experimental host for plant viruses. Plant Disease, 86, 13101314.

Awondo, S. N., Fonsah, E. G., Riley, D., \& Abney, M. (2012). Effectiveness of Tomato spotted wilt virus management tactics. Journal of Economic Entomology, 105(3), 943-948.

Blacksell, S. D., Khouny, S., \& Westbury, H. A. (2004). The effect of sample degradation and RNA stabilization on classical 
fever virus RT-PCR and ELISA methods. Journal of Virological Methods, 118, 33-37.

Brittlebank, C. C. (1919). Tomato diseases. Journal of Agriculture, 27, 231-235.

Chen, T. -C., Li, J. -T., Lin, Y. -P., Yeh, Y. -C., Kang, Y. -C., Huang, L. -H., \& Yeh, S. -D. (2012). Genomic characterization of Calla lily chlorotic spot virus and design of broadspectrum primers for detection of tospoviruses. Plant Pathology, 61, 183-194.

Cho, J. J., Custer, D. M., Brommonschenkel, S. H., \& Tanksley, S. D. (1996). Conventional breeding: Host-plant resistance and the use of molecular markers to develop resistance to Tomato spotted wilt virus in vegetables. Acta Horticulturae, 431, 367-378.

EFSA Panel on Plant Health. (2012). Scientific opinion on the pest categorization of the tospoviruses. EFSA Journal, 10, 2772.

German, L. T., Ulman, D. E., \& Moyer, J. W. (1992). Tospoviruses: Diagnosis, molecular biology, phylogeny and vector relationships. Annual Review of Phytopathology, 30, 315-348.

Goldbach, R., \& Peters, D. (1994). Possible causes of tospovirus diseases. Seminars in Virology, 5, 113-120.

Hoffmann, K., Qiu, W. P., \& Moyer, J. W. (2001). Overcoming host- and pathogen-mediated resistance in tomato and tobacco maps to the M RNA of Tomato spotted wilt virus. Molecular Plant-Microbe Interactions, 14, 242-249.

Hopkins, J. C. F. (1940). The tobacco 'kromnek' virus in Rhodesia. Rhodesia Agricultural Journal, 37(6), 326-329.

Karavina, C., \& Gubba, A. (2017a). Amaranthus sp. and Eleusine indica are natural hosts of Iris yellow spot virus in Zimbabwe. Plant Disease, 101(1), 262.

Karavina, C., \& Gubba, A. (2017b). Iris yellow spot virus in Zimbabwe: Incidence, severity and characterization of Allium-infecting isolates. Crop Protection, 94, 69-76.

Macharia, I., Backhouse, D., Ateka, E. M., Wu, S. -B., Harvey, J., Njahira, M., \& Skilton, R. A. (2015). Distribution and genetic diversity of Tomato spotted wilt virus following an incursion into Kenya. Annals of Applied Biology, 166, 520-529.

Macharia, I., Backhouse, D., Wu, S. -B., \& Ateka, E. M. (2016). Weed species in tomato production and their role as alternative hosts of Tomato spotted wilt virus and its vector Frankliniella occidentalis. Annals of Applied Biology, 169, 224-235.

Massumi, H., Samei, A., Pour, A. H., \& Shaabanian, M. (2007). Occurrence, distribution and relative incidence of seven viruses infecting greenhouse-grown cucurbits in Iran. Plant Disease, 91(2), 159-163.

Masuka, A. J., Cole, D. L., \& Mguni, C. (1998). List of plant diseases in Zimbabwe. Plant Protection Research Institute: Harare.

Naidu, R. A., \& Hughes, J. D. A. (2003). Methods for the detection of plant viruses. In Plant Virology in Sub-Saharan Africa, Proceedings of Conference Organized by IITA, J.d'A. Hughes and J. Odu (Ed.), International Institute of tropical Agriculture (pp. 233-260). Nigeria: Ibadan.

Navarre, D. A., Shakya, R., Holden, J., \& Crosslin, J. M. (2009). LC-MS analysis of phenolic compounds in tubers showing zebra chip symptoms. American Journal of Potato Research, $86,88-95$.
Nischwitz, C., Mullis, S. W., Gitaitis, R. D., \& Csinos, A. S. (2006). First report of Tomato spotted wilt virus in soyabean (Glycine max) in Georgia. Plant Disease, 90, 524.

Nyamupingidza, T. N., \& Machakaire, V. (2003). Virus diseases of important vegetables in Zimbabwe. In J.'. A. Hughes \& J. Odu (Eds.), In: Plant Virology in Sub-Saharan Africa, Proc.Conf. Organized by IITA (pp. 397-406). Ibadan, Nigeria: International Institute of tropical Agriculture.

Okuda, M., \& Hanada, K. (2001). RT-PCR for detecting five distinct Topsovirus species using degenerate primers and dsRNA template. Journal of Virological Methods, 96, 149156.

Pappu, H. R., \& Subramanian, S. (2013). Ever increasing diversity of tospoviruses: Implications for Africa. In Proceedings of the $12^{\text {th }}$ International symposium on plant virus epidemiology, 28 January - 1 February 2013. Arusha: Tanzania.

Pappu, H. R., Jones, R. A. C., \& Jain, R. K. (2009). Global status of Tospovirus epidemics in diverse cropping systems: Successes achieved and challenges ahead. Virus Research, 141, 219-236.

Parrella, G., Gognalous, P., Gebre-Selassie, K., Vovlas, C., \& Marchoux, G. (2003). An update on the host range of Tomato spotted wilt virus. Journal of Plant Pathology, 85, 227-264.

Rader, J. S., Malone, J. P., Goss, J., Gilmore, P., Brooks, R. A., Nguyen, L., et al. (2008). A unified sample preparation protocol for proteomic and genomic profiling of cervical swabs to identify biomarkers for cervical cancer screening. Proteomics Clinical Applications, 2(12), 1658-1669.

Riley, D. G., Shimat, V. J., Srinivasan, R., \& Diffle, S. (2011). Thrips vectors of tospoviruses. Journal of Integrated Pest Management, 1(2), 1-10.

Robbins, M. D., Masud, M. A. T., Panthee, D. R., Gardner, R. G., Francis, D. M., \& Stevens, M. R. (2010). Marker assisted selection for coupling resistance to Tomato spotted wilt virus and Phytophthora infestans in tomato. Hort Science, 45(10), 1424-1428.

Roberts, C. A., Dietzgen, R. G., Heelan, L. A., \& Maclean, D. J. (2000). Realtime RT-PCR fluorescent detection of Tomato spotted wilt virus. Journal of Virological Methods, 88, 1-8.

Rotenberg, D., Jacobson, A. L., Schneweis, D. J., \& Whitfield, A. E. (2015). Thrips transmission of tospoviruses. Current Opinion in Virology, 15, 80-89.

Rothwell, A. (1982). A revised list of plant diseases occurring in Zimbabwe. Kirkia, 12(2), 233-352.

Scholthof, K. -B. G., Adkins, S., Czosnek, H., Palukaitis, P., Jacquot, E., Horn, T., et al. (2011). Top 10 plant viruses in molecular plant pathology. Molecular Plant Pathology, 12(9), 938-954.

Sether, D. M., \& DeAngelis, J. D. (1992). Tomato spotted wilt virus host list and bibliography. In Special Report 888 (17 pp). Agricultural Experiment Station: Oregon State University.

Sevik, M. A., \& Arli-Sokmen, M. (2012). Estimation of the effect of Tomato spotted wilt virus (TSWV) infection time on some yield components of tomato. Phytoparasitica, 40, 87-93.

Sharman, M., \& Persley, D. M. (2006). Field isolates of Tomato spotted wilt virus overcoming resistance in capsicum in Australia. Australasian Plant Pathology, 35, 123-128. 
Sivparsad, B. J., \& Gubba, A. (2008). Isolation and molecular characterization of Tomato spotted wilt virus (TSWV) isolates occurring in South Africa. African Journal of Agricultural Research, 3(6), 428-434.

Strange, R. N. (2003). Introduction to plant pathology. England: John Wiley and Sons Ltd.

Tamura, K. (1992). Estimation of the number of nucleotide substitutions when there are strong transition-transversion and $\mathrm{G}$ + C-content biases. Molecular Biology and Evolution, 9, 678-687.

Tamura, K., Stecher, G., Peterson, D., Filipski, A., \& Kumar, S. (2013). MEGA6: Molecular evolutionary genetics analysis version 6.0. Molecular Biology and Evolution, 30, 27252729.
Tsompana, M., Abad, J., Purugganan, M., \& Moyer, J. W. (2005). The molecular population genetics of Tomato spotted wilt virus (TSWV) genome. Molecular Ecology, 14, 53-66.

Turina, M., Tavella, L., \& Ciuffo, M. (2012). Tospoviruses in the Mediterranean area. Advances in Virus Research, 84, 403437.

Whitfield, A. E., Ullman, D. E., \& German, T. L. (2005). Tospovirusthrips interaction. Annual Review of Phytopathology, 43, 459489.

Zindovic, J., Ciuffo, M., \& Turina, M. (2014). Molecular characterization of Tomato spotted wilt virus in Montenegro. Journal of Plant Pathology, 96(1), 201-205. 